\title{
Phosphatidylinositol 4-Kinase Beta
}

National Cancer Institute

\section{Source}

National Cancer Institute. Phosphatidylinositol 4-Kinase Beta. NCI Thesaurus. Code C30173.

Phosphatidylinositol 4-kinase beta (816aa, $291 \mathrm{kDa}$ ) is encoded by the human PI4KB gene. This protein plays a role in the first step of inositol-1,4,5,-trisphosphate production. 